\title{
Effect of Ca Content on the Mechanical Properties and Corrosion Behaviors of Extruded Mg-7Li-3Al Alloys
}

\author{
Xiaoming Xiong ${ }^{1}$, Yan Yang ${ }^{1,2, *}$, Hongju Deng ${ }^{1}$, Minmin $\mathrm{Li}^{1}{ }^{1}$, Jinguang $\mathrm{Li}^{1}{ }^{1}$, Guobing Wei ${ }^{1,2}$ \\ and Xiaodong Peng ${ }^{1,2}$ \\ 1 International Joint Laboratory for Light Alloys (MOE), College of Materials Science and Engineering, \\ Chongqing University, Chongqing 400044, China; 20160913127@cqu.edu.cn (X.X.); \\ 201809131132@cqu.edu.cn (H.D.); 20180902041t@cqu.edu.cn (M.L.); 201709021013@cqu.edu.cn (J.L.); \\ guobingwei@cqu.edu.cn (G.W.); pxd@cqu.edu.cn (X.P.) \\ 2 National Engineering Research Center for Magnesium Alloys, Chongqing University, \\ Chongqing 400044, China \\ * Correspondence: yanyang@cqu.edu.cn; Tel.: +86-23-6510-2856
}

Received: 14 October 2019; Accepted: 6 November 2019; Published: 11 November 2019

Abstract: The effect of $\mathrm{Ca}$ addition on the microstructure, mechanical properties, and corrosion behaviors of the extruded $\mathrm{Mg}-7 \mathrm{Li}-3 \mathrm{Al}$ alloys was investigated. The results showed that the extruded $\mathrm{Mg}-7 \mathrm{Li}-3 \mathrm{Al}-\mathrm{xCa}$ alloys consisted of $\alpha-\mathrm{Mg}(\mathrm{hcp})+\beta-\mathrm{Li}(\mathrm{bcc})$ matrix phases and $\mathrm{Al}_{2} \mathrm{Ca}$. With increasing $\mathrm{Ca}$ content, the amount and morphology of the $\mathrm{Al}_{2} \mathrm{Ca}$ phase changed significantly. The grains of the extruded $\mathrm{Mg}-7 \mathrm{Li}-3 \mathrm{Al}-\mathrm{xCa}$ alloys were refined by dynamic recrystallization during the extrusion process. The tensile tests results indicated that the extruded $\mathrm{Mg}-7 \mathrm{Li}-3 \mathrm{Al}-0.4 \mathrm{Ca}$ alloy exhibited favorable comprehensive mechanical properties; its ultimate tensile strength was $286 \mathrm{MPa}$, the yield strength was $249 \mathrm{MPa}$, and the elongation was $18.7 \%$. The corrosion results showed that this alloy with $0.4 \mathrm{wt} . \% \mathrm{Ca}$ addition exhibited superior corrosion resistance, with a corrosion potential $E_{\text {corr }}$ of $-1.48742 \mathrm{~V}_{\mathrm{VSE}}$, attributed to the formation of protective $\mathrm{Al}_{2} \mathrm{Ca}$ phases.

Keywords: $\mathrm{Mg}-7 \mathrm{Li}-3 \mathrm{Al}$ alloy; extrusion; mechanical properties; corrosion

\section{Introduction}

$\mathrm{Mg}-\mathrm{Li}$ alloys have been applied in automatic, 3C (Computer, Communication, Consumer Electronic) products and communication electronics fields for more than a decade owing to the high specific strength and advantageous formability [1-4]. However, their poor creep resistance and inferior corrosion resistance usually limit their application [5,6]. In order to solve the existing problems, many alloying elements $(\mathrm{Al}, \mathrm{Ca})$ have been used to improve the mechanical properties and corrosion resistance of $\mathrm{Mg}-\mathrm{Li}$ alloys [7-9].

Some studies showed that $\mathrm{Al}$ can improve the mechanical properties of $\mathrm{Mg}-\mathrm{Li}$ alloys owing to the formation of intermetallic compounds and a favorable solid-solution strengthening effect [10-14]. Bahman et al. [15] reported that more than $3 \mathrm{wt} . \%$ addition of $\mathrm{Al}$ dramatically degraded the corrosion resistance of $\mathrm{Mg}-\mathrm{Al}-\mathrm{Zn}-\mathrm{Ca}$ alloys due to the formation of a $\mathrm{Mg}_{17} \mathrm{Al}_{12}$ network at the grain boundaries. Some research indicated that the formation of this $\mathrm{Mg}_{17} \mathrm{Al}_{12}$ phase can be inhibited by the addition of Ca [16-19].

It has been reported that $\mathrm{Ca}$ can improve the corrosion resistance of $\mathrm{Mg}$ alloys by the formation of protective $\mathrm{Al}_{2} \mathrm{Ca}$ and $(\mathrm{Mg}, \mathrm{Al})_{2} \mathrm{Ca}$ phases. At the same time, their high-temperature mechanical properties are also improved by grain refinement [20,21]. Li Zhang et al. [19] revealed that the microstructure and mechanical properties of $\mathrm{Mg}-\mathrm{Al}-\mathrm{Ca}$ alloys were affected by the $\mathrm{Ca} / \mathrm{Al}$ ratio, indicating that the strengthening effect of the $\mathrm{Al}_{2} \mathrm{Ca}$ phase was better than that of the $\mathrm{Mg}_{2} \mathrm{Ca}$ phase. Wang et al. [22] showed that extruded $\mathrm{Mg}-5 \mathrm{Li}-3 \mathrm{Al}-0.5 \mathrm{Ca}$ alloy had the highest strength. 
However, while reviewing the published literature, we found few reports about the influence of $\mathrm{Ca}$ and $\mathrm{Al}$ additions on the corrosion behaviors and mechanical properties of $\alpha$ (hcp) $+\beta$ (bcc) dual-structured $\mathrm{Mg}-\mathrm{Li}$ alloys. Thus, the effect of the addition of different $\mathrm{Ca}$ amounts on the mechanical properties and corrosion behavior of $\alpha(\mathrm{hcp})+\beta(\mathrm{bcc})$ dual-structured Mg-7Li-3Al-xCa $(\mathrm{x}=0,0.4,0.8$, $1.2 \mathrm{wt} . \%)$ alloys were investigated.

\section{Experimental Procedures}

Mg-7Li-3Al-xCa (x = 0, 0.4, 0.8, 1.2 wt.\%) alloys [Mg, $\mathrm{Al}$, and $\mathrm{Li}(99.9 \%)$ and $\mathrm{Mg}-30 \mathrm{Ca}$ master alloy (wt.\%)] were melted in a melting furnace, protected by a $\mathrm{SF}_{6} / \mathrm{CO}_{2}$ gas mixture. The molten metal was cast in a cylinder metal mold and then was homogenized in a vacuum furnace at $250{ }^{\circ} \mathrm{C}$ for $4 \mathrm{~h}$. Finally, the ingots, $80 \mathrm{~mm}$ in diameter, were extruded at $250^{\circ} \mathrm{C}$ (extrusion ratio was $25: 1$ ). The chemical compositions of the alloys are listed in Table 1.

Table 1. Chemical composition of the extruded alloys.

\begin{tabular}{ccccc}
\hline \multirow{2}{*}{ Materials } & \multicolumn{4}{c}{ Chemical Composition (wt.\%) } \\
\cline { 2 - 5 } & Li & Al & Ca & Mg \\
\hline Mg-7Li-3Al & 6.85 & 2.78 & - & Bal. \\
Mg-7Li-3Al-0.4Ca & 7.21 & 2.85 & 0.38 & Bal. \\
Mg-7Li-3Al-0.8Ca & 6.49 & 3.12 & 0.87 & Bal. \\
Mg-7Li-3Al-1.2Ca & 6.76 & 2.75 & 1.15 & Bal. \\
\hline
\end{tabular}

The microstructure of the alloys was analyzed by optical microscopy (OM; OLYMPUS PMG3, Shinjuku, Japan) and scanning electron microscopy (SEM; FEI NOVA 400, Tallahassee, FL, USA). Tensile tests at room temperature and high temperature $\left(150{ }^{\circ} \mathrm{C}\right)$ were conducted on a tensile tester (SANS CMT-5105, Mohd Sultan Road, Singapore) with a displacement speed of $2 \mathrm{~mm} / \mathrm{min}$. In addition, the phase composition of the alloys was analyzed by X-ray diffraction (XRD; D/max-2500pc, Tokyo, Japan).

Cylindrical samples of $\Phi 16 \mathrm{~mm} \times 9 \mathrm{~mm}$ were machined from the extruded alloy bar and then ground to cylindrical samples of $\Phi 15 \mathrm{~mm} \times 7 \mathrm{~mm}$. The size and weight of the samples were measured before the experiment, then the samples were placed in a $3.5 \mathrm{wt} . \% \mathrm{NaCl}$ aqueous solution. After immersion for $72 \mathrm{~h}$, the samples were cleaned with $200 \mathrm{~g} \mathrm{~L}^{-1} \mathrm{CrO}_{3}$ and weighed again. The corrosion rate was calculated by:

$$
c_{w}=2.1 \times \Delta m /(A t)
$$

where $c_{w}$ is the corrosion rate in $\mathrm{mm} / \mathrm{year}, \Delta m$ is the weight loss in $\mathrm{mg}, A$ is the surface area in $\mathrm{cm}^{2}$, and $t$ is the immersion time in days. The electrochemical experiments were carried out by a GAMRY Reference 600+ system, and a three-electrode electrochemical cell was used at room temperature in a $3.5 \mathrm{wt} \% \mathrm{NaCl}$ solution. Potentiodynamic polarization tests were implemented from $-1.9 \mathrm{~V}$ vs. SCE (Saturated calomel electrode) to $-1 \mathrm{~V}$ vs. SCE, with a scan rate of $0.5 \mathrm{mV} / \mathrm{s}$. All electrochemical tests were performed 3 times to obtain the average of the corrosion potential $\left(E_{c o r r}, V\right.$ vs. SCE) and the corrosion current density $\left(i_{c o r r}, \mathrm{~A} \mathrm{~cm}^{-2}\right)$. The frequency range for electrochemical impedance spectroscopy (EIS) testing was $10^{5}-10^{-2} \mathrm{~Hz}$, and the amplitude of the applied sine wave disturbance was $10 \mathrm{mV}$. The measured data were analyzed, and the equivalent circuit parameters were obtained by Z-View software (Scribner Associates, Inc., Southern Pines, NC, USA). 


\section{Results}

\subsection{Microstructure}

Optical micrographs of the extruded alloys are shown in Figures 1 and 2. According to the Figure 2a, the average grain size of the extruded $\mathrm{Mg}-7 \mathrm{Li}-3 \mathrm{Al}$ alloy was approximately $6.98 \mu \mathrm{m}$. After incrementing $\mathrm{Ca}$, the average grain sizes of the $\mathrm{Mg}-7 \mathrm{Li}-3 \mathrm{Al}-0.4 \mathrm{Ca}$ and $\mathrm{Mg}-7 \mathrm{Li}-3 \mathrm{Al}-0.8 \mathrm{Ca}$ alloys were approximately $5.14 \mu \mathrm{m}$ and $6.39 \mu \mathrm{m}$, respectively. The extruded $\mathrm{Mg}-7 \mathrm{Li}-3 \mathrm{Al}-1.2 \mathrm{Ca}$ alloy had the minimum grains size, with an average value of $3.92 \mu \mathrm{m}$, as shown in Figure 2d. According to previous research [23], the dark areas in the figures can be identified as $\alpha-\mathrm{Mg}$ phase, and the grey areas as $\beta$-Li phase. It appeared that the $\alpha-\mathrm{Mg}$ and $\beta$-Li phases were elongated along the extrusion direction, while the intermetallic compounds were mainly distributed at the boundaries of the $\alpha$-Mg and $\beta$-Li phases and at the grain boundaries.

The XRD patterns of the extruded $\mathrm{Mg}-7 \mathrm{Li}-3 \mathrm{Al}-\mathrm{xCa}$ alloys are presented in Figure 3. It is obvious that the Mg-7Li-3Al alloy mainly contained $\alpha-\mathrm{Mg}, \beta-\mathrm{Li}$ matrix, AlLi, and $\mathrm{Mg}_{17} \mathrm{Al}_{12}$ phases. With addition of 0.4 wt. $\% \mathrm{Ca}, \mathrm{Mg}_{17} \mathrm{Al}_{12}$ disappeared, while $\mathrm{Al}_{2} \mathrm{Ca}$ formed. When the amount of Ca was 0.8 wt.\% and 1.2 wt.\%, there was only $\mathrm{Al}_{2} \mathrm{Ca}$ as the second phase in the extruded alloys. The difference in electronegativity between $\mathrm{Mg}$ and $\mathrm{Al}$ is 0.3 , while that between $\mathrm{Al}$ and $\mathrm{Li}$ is 0.63 [14]. Hence, the AlLi phase forms more easily than the $\mathrm{Mg}_{17} \mathrm{Al}_{12}$ phase. Thus, the compounds in the $\mathrm{Mg}-7 \mathrm{Li}-3 \mathrm{Al}$ alloy contained $\mathrm{AlLi}$ and a small amount of $\mathrm{Mg}_{17} \mathrm{Al}_{12}$. Similarly, the difference in electronegativity between $\mathrm{Al}$ and $\mathrm{Ca}$ is 0.5 , while that between $\mathrm{Mg}$ and $\mathrm{Ca}$ is 0.21 ; thus, it is obvious that $\mathrm{Al}$ reacts with $\mathrm{Ca}$ more likely than $\mathrm{Mg}$. Thus, $\mathrm{Al}_{2} \mathrm{Ca}$ forms more easily in alloys containing $\mathrm{Ca}$ [11].
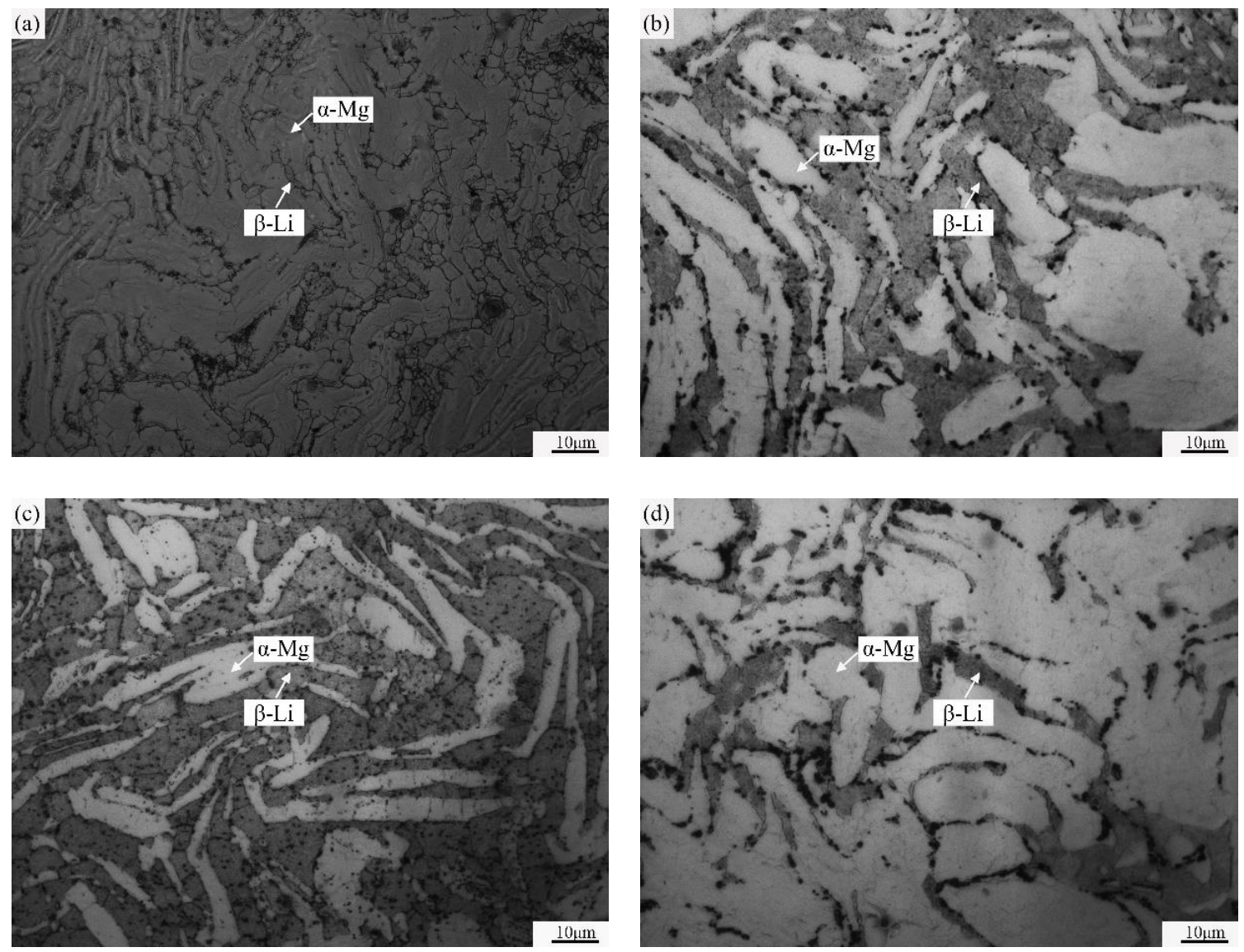

Figure 1. Microstructures of the extruded $\mathrm{Mg}-7 \mathrm{Li}-3 \mathrm{Al}-\mathrm{xCa}$ alloys (perpendicular to the extrusion direction): $(\mathbf{a}) \mathrm{x}=0$ (b) $\mathrm{x}=0.4(\mathbf{c}) \mathrm{x}=0.8(\mathrm{~d}) \mathrm{x}=1.2$. 

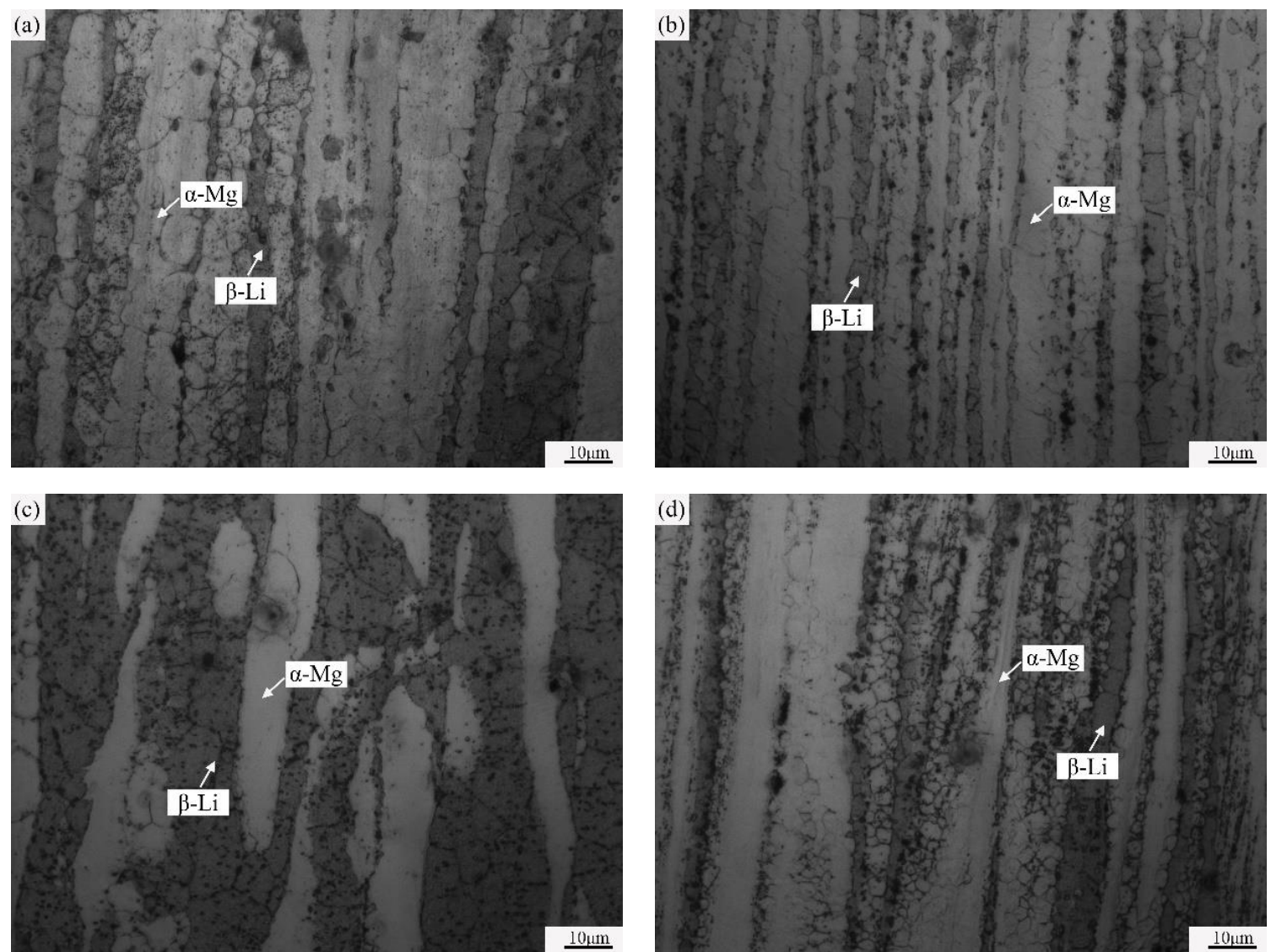

Figure 2. Microstructures of the extruded $\mathrm{Mg}-7 \mathrm{Li}-3 \mathrm{Al}-\mathrm{xCa}$ alloys (parallel to the extrusion direction): (a) $\mathrm{x}=0$ (b) $\mathrm{x}=0.4$ (c) $\mathrm{x}=0.8(\mathrm{~d}) \mathrm{x}=1.2$.

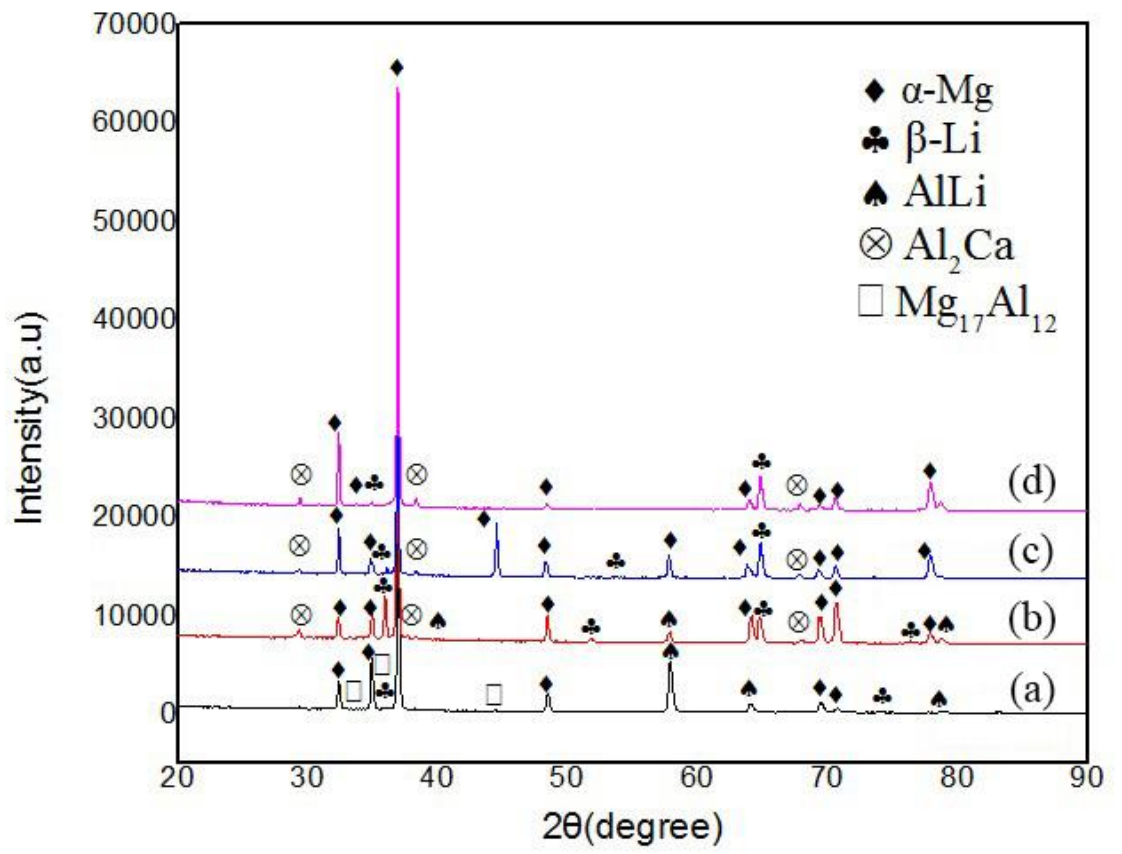

Figure 3. XRD patterns of the extruded $\mathrm{Mg}-7 \mathrm{Li}-3 \mathrm{Al}-\mathrm{xCa}$ alloys: $(\mathbf{a}) \mathrm{x}=0(\mathbf{b}) \mathrm{x}=0.4(\mathbf{c}) \mathrm{x}=0.8$ (d) $x=1.2$.

The SEM images of the alloys are presented in Figure 4. The EDS analysis results of the points in Figure 4 are listed in Table 2. In the $\mathrm{Mg}-7 \mathrm{Li}-3 \mathrm{Al}$ alloy (Figure 4a), some bright particles (labeled as A) 
were distributed at the phase boundaries and inside the $\alpha-\mathrm{Mg}$ phase. The EDS results indicated that the compound contained $\mathrm{Mg}$ and $\mathrm{Al}$ at a mole ratio of $\sim 17: 12$. Combined with the XRD data shown in Figure 3, the results indicate that the bright particles can be identified as $\mathrm{Mg}_{17} \mathrm{Al}_{12}$. In Figure $4 \mathrm{~b}$, the bright particles (marked as $\mathrm{B}$ ) were identified as $\mathrm{Al}_{2} \mathrm{Ca}$ by combined EDS and XRD analyses. The EDS analysis showed that the short strip of intermetallic compound (marked as $\mathrm{C}$ ) shown in Figure $4 \mathrm{~b}$ consisted of $\mathrm{Mg}, \mathrm{Al}$, and $\mathrm{Ca}$, with a mole ratio of $\mathrm{Al}$ to $\mathrm{Ca}$ of approximately 2.4:1, which indicated that this strip contained an $\mathrm{Al}_{2} \mathrm{Ca}$ phase. According to a previous study, [24] the mass ratio of $\mathrm{Ca} / \mathrm{Al}$ in $\mathrm{Mg}-\mathrm{Al}-\mathrm{Ca}$ alloys determines the types of intermetallic compounds. Only $\mathrm{Al}_{2} \mathrm{Ca}$ exists in the alloys when the $\mathrm{Ca} / \mathrm{Al}$ mass ratio is less than 0.8 . Since the $\mathrm{Ca} / \mathrm{Al}$ mass ratio in the $\mathrm{Mg}-7 \mathrm{Li}-3 \mathrm{Al}-0.4 \mathrm{Ca}$ alloy was approximately 0.13 , the eutectic phase was expected to be $\mathrm{Al}_{2} \mathrm{Ca}$. Similarly, the compounds marked as D, E, and $\mathrm{F}$ in Figure $4 \mathrm{c}$, d were inferred to contain $\mathrm{Al}_{2} \mathrm{Ca}$ by EDS and XRD analyses. With increasing Ca content, these $\mathrm{Al}_{2} \mathrm{Ca}$ compounds were observed to gradually aggregate into strips. The average size of these strip-shaped compounds in Figure $4 \mathrm{~d}$ was approximately $16.31 \mu \mathrm{m}$.
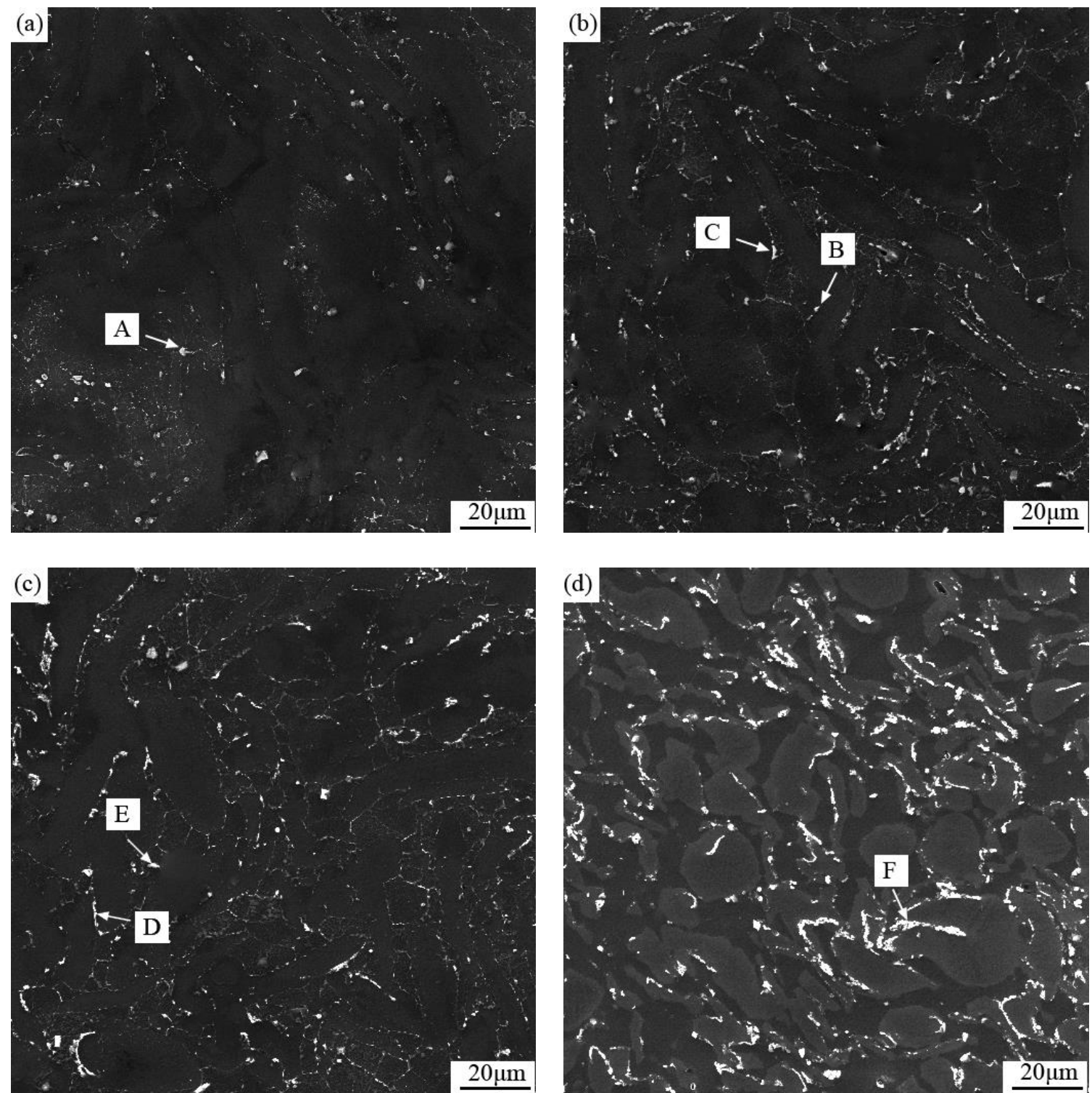

Figure 4. SEM images of the Mg-7Li-3Al-xCa alloys: $(\mathbf{a}) \mathrm{x}=0(\mathbf{b}) \mathrm{x}=0.4(\mathbf{c}) \mathrm{x}=0.8(\mathrm{~d}) \mathrm{x}=1.2$. 
Table 2. EDS result corresponding to different positions in Figure 4. (mole fraction, \%).

\begin{tabular}{cccc}
\hline Position & Mg & Al & Ca \\
\hline A & 61.12 & 38.88 & 0 \\
B & 0 & 65.88 & 34.12 \\
C & 75.44 & 16.67 & 7.89 \\
D & 59.51 & 27.38 & 13.11 \\
E & 0 & 51.46 & 48.54 \\
F & 0 & 68.54 & 36.46 \\
\hline
\end{tabular}

\subsection{Mechanical Properties}

Figure 5 presents the stress-strain curves of the extruded alloys. The values obtained from these curves are listed in Table 3. When the amount of Ca was $0.4 \%$, the ultimate tensile strength (UTS) of the alloy reached a maximum of $286 \mathrm{MPa}$, while the UTS of the alloy without Ca was $268 \mathrm{MPa}$. Therefore, the addition of $0.4 \%$ of $\mathrm{Ca}$ can increase the tensile strength of the $\mathrm{Mg}-7 \mathrm{Li}-3 \mathrm{Al}$ alloy. The UTS and elongation of the extruded $\mathrm{Mg}-7 \mathrm{Li}-3 \mathrm{Al}-0.4 \mathrm{Ca}$ alloy were improved by $\sim 6.8 \%$ and $14.7 \%$, respectively, compared to those of the $\mathrm{Mg}-7 \mathrm{Li}-3 \mathrm{Al}$ alloy. When the addition of $\mathrm{Ca}$ exceeded $0.8 \%$, the tensile yield strength (TYS) and the UTS exhibited a slight decline. The TYS and UTS of the $\mathrm{Mg}-7 \mathrm{Li}-3 \mathrm{Al}-1.2 \mathrm{Ca}$ alloy decreased $26 \mathrm{MPa}$ and $30 \mathrm{MPa}$, respectively, compared to those of the $\mathrm{Mg}-7 \mathrm{Li}-3 \mathrm{Al}$ alloy, while the elongation improved by addition of Ca.

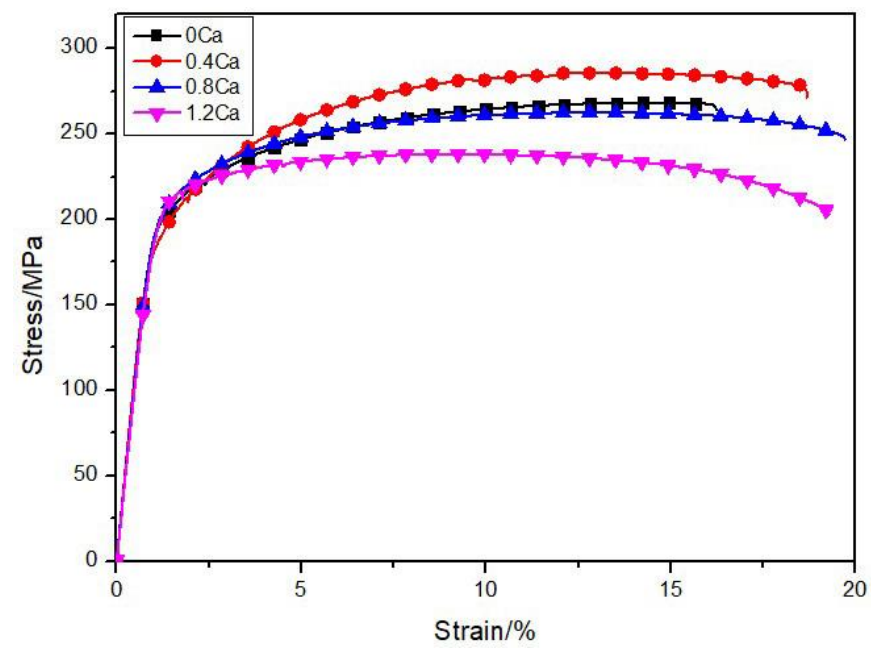

Figure 5. Stress-strain curves of the extruded $\mathrm{Mg}-7 \mathrm{Li}-3 \mathrm{Al}-\mathrm{xCa}$ alloys at room temperature.

Table 3. Mechanical properties of the extruded $\mathrm{Mg}-7 \mathrm{Li}-3 \mathrm{Al}-\mathrm{xCa}$ test alloys at room temperature.

\begin{tabular}{cccc}
\hline Extruded Alloys & TYS (MPa) & UTS (MPa) & Elongation (\%) \\
\hline Mg-7Li-3Al & 233 & 268 & 16.3 \\
Mg-7Li-3Al-0.4Ca & 249 & 286 & 18.7 \\
Mg-7Li-3Al-0.8Ca & 229 & 263 & 19.7 \\
Mg-7Li-3Al-1.2Ca & 207 & 238 & 19.3 \\
\hline
\end{tabular}

Figure 5 presents the stress-strain curves of the extruded alloys at $423 \mathrm{~K}\left(150^{\circ} \mathrm{C}\right)$. The Mechanical properties of the extruded $\mathrm{Mg}-7 \mathrm{Li}-3 \mathrm{Al}-\mathrm{xCa}$ alloys at $423 \mathrm{~K}\left(150^{\circ} \mathrm{C}\right)$ are listed in Table 4 . According to Figure 6 and Table 4, with increasing Ca content, the TYS of the experimental alloys at $423 \mathrm{~K}$ $\left(150{ }^{\circ} \mathrm{C}\right)$ first increased and then decreased. The extruded $\mathrm{Mg}-7 \mathrm{Li}-3 \mathrm{Al}-0.4 \mathrm{Ca}$ alloy exhibited good high-temperature mechanical properties, with a TYS of $191 \mathrm{MPa}$, which improved by $22.4 \%$ compared to the TYS of the $\mathrm{Mg}-6.8 \mathrm{Li}-3 \mathrm{Al}$ alloy. The $\mathrm{Al}_{2} \mathrm{Ca}$ phase, with a melting point of $1079^{\circ} \mathrm{C}$ and notable high-temperature stability, promotes strength improvement. The elongation of the test alloys first 
decreased and then increased with increasing Ca content. The extruded alloy with a Ca content of $1.2 \mathrm{wt} . \%$ underwent the largest elongation, reaching a value of $24.8 \%$.

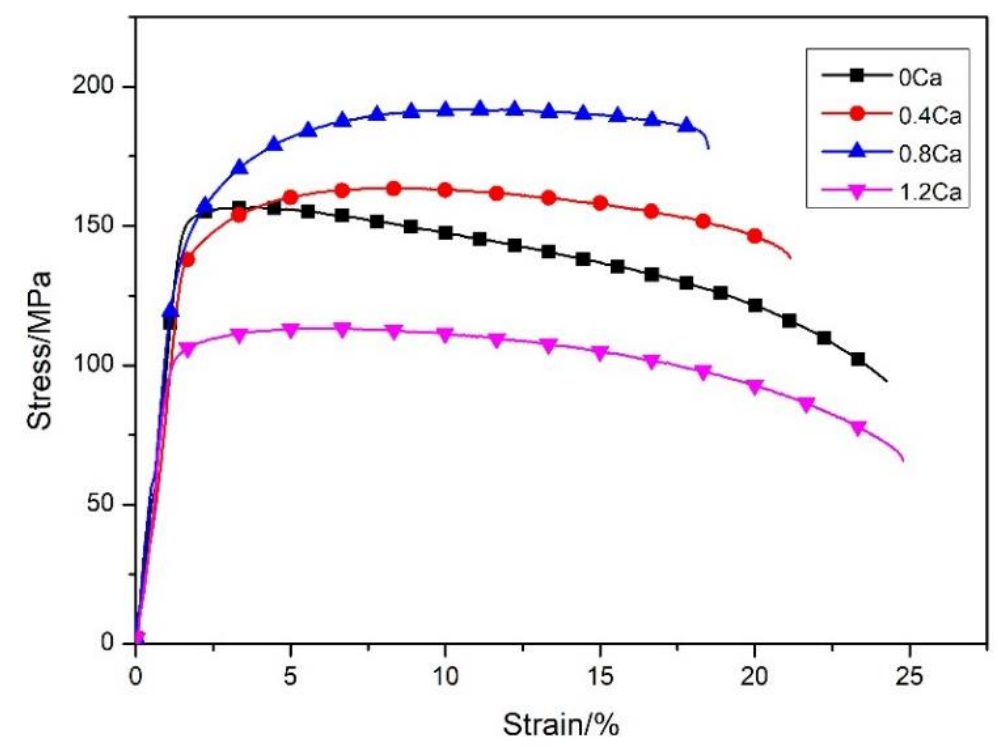

Figure 6. Stress-strain curves of extruded Mg-7Li-3Al-xCa alloys at $423 \mathrm{~K}\left(150^{\circ} \mathrm{C}\right)$.

Table 4. Mechanical properties of the extruded $\mathrm{Mg}-7 \mathrm{Li}-3 \mathrm{Al}-\mathrm{xCa}$ alloys at $423 \mathrm{~K}\left(150^{\circ} \mathrm{C}\right)$.

\begin{tabular}{cccc}
\hline Extruded Alloys & TYS (MPa) & UTS (MPa) & Elongation (\%) \\
\hline Mg-7Li-3Al & 145 & 156 & 24.3 \\
Mg-7Li-3Al-0.4Ca & 141 & 163 & 21.1 \\
Mg-7Li-3Al-0.8Ca & 163 & 191 & 18.5 \\
Mg-7Li-3Al-1.2Ca & 98 & 113 & 24.8 \\
\hline
\end{tabular}

\subsection{Corrosion Behavior}

Figure 7 shows the potentiodynamic polarization behaviors of the test alloys in a $3.5 \mathrm{wt} . \%$ $\mathrm{NaCl}$ solution. The values obtained from these curves are listed in Table 5. The corrosion potential ( $E_{\text {corr }}, \mathrm{V}$ vs. SCE) for the $\mathrm{Mg}-7 \mathrm{Li}-3 \mathrm{Al}$ alloy was $-1.5445 \mathrm{~V}_{\mathrm{VSE}}$, while those for the $\mathrm{Mg}-7 \mathrm{Li}-3 \mathrm{Al}-0.4 \mathrm{Ca}$, $\mathrm{Mg}-7 \mathrm{Li}-3 \mathrm{Al}-0.8 \mathrm{Ca}$, and $\mathrm{Mg}-7 \mathrm{Li}-3 \mathrm{Al}-1.2 \mathrm{Ca}$ alloys containing $\mathrm{Ca}$, were $-1.48742 \mathrm{~V}_{\mathrm{VSE}},-1.4940 \mathrm{~V}_{\mathrm{VSE}}$, and $-1.4799 \mathrm{~V}_{\mathrm{VSE}}$, respectively. The $E_{\text {corr }}$ of the alloys improved substantially by the addition of Ca. Furthermore, with increasing Ca content, the corrosion current density $\left(i_{\text {corr }}, \mathrm{A} \mathrm{cm}^{-2}\right)$ of the alloys decreased. The breakdown potential $\left(E_{b}\right)$ was detected at $-1.3735 \mathrm{~V}$ (vs. SCE) for the extruded $\mathrm{Mg}-7 \mathrm{Li}-3 \mathrm{Al}-1.2 \mathrm{Ca}$ alloy, as shown in Table 5. The extruded alloy with a Ca content of $1.2 \mathrm{wt} . \%$ and the lowest corrosion current density $\left(31 \mu \mathrm{A} \mathrm{cm}{ }^{2}\right)$ exhibited the best corrosion resistance among the alloys. It can be inferred that the passive film formed on the $\mathrm{Mg}-7 \mathrm{Li}-3 \mathrm{Al}-1.2 \mathrm{Ca}$ alloy was relatively stable due to its high $E_{b}$ value.

Table 5. Values obtained from the potentiodynamic polarization tests (in Figure 7).

\begin{tabular}{ccccc}
\hline Alloys & $E_{\text {corr }}(\mathbf{V}$ vs. SCE $)$ & $\boldsymbol{E}_{\boldsymbol{b}}(\mathbf{V}$ vs. SCE) & $\boldsymbol{\beta}_{\boldsymbol{c}}(\mathbf{m V} / \mathbf{d e c})$ & $\boldsymbol{i}_{\text {corr }}\left(\boldsymbol{\mu} \mathrm{A} / \mathrm{cm}^{2}\right)$ \\
\hline Mg-7Li-3Al & -1.5445 & - & -342.18 & 134.90 \\
$\mathrm{Mg}-7 \mathrm{Li}-3 \mathrm{Al}-0.4 \mathrm{Ca}$ & -1.48742 & - & -240.84 & 39.81 \\
$\mathrm{Mg}-7 \mathrm{Li}-3 \mathrm{Al}-0.8 \mathrm{Ca}$ & -1.4940 & - & -294.18 & 63.10 \\
$\mathrm{Mg}-7 \mathrm{Li}-3 \mathrm{Al}-1.2 \mathrm{Ca}$ & -1.4799 & -1.3735 & -260.61 & 31.62 \\
\hline
\end{tabular}




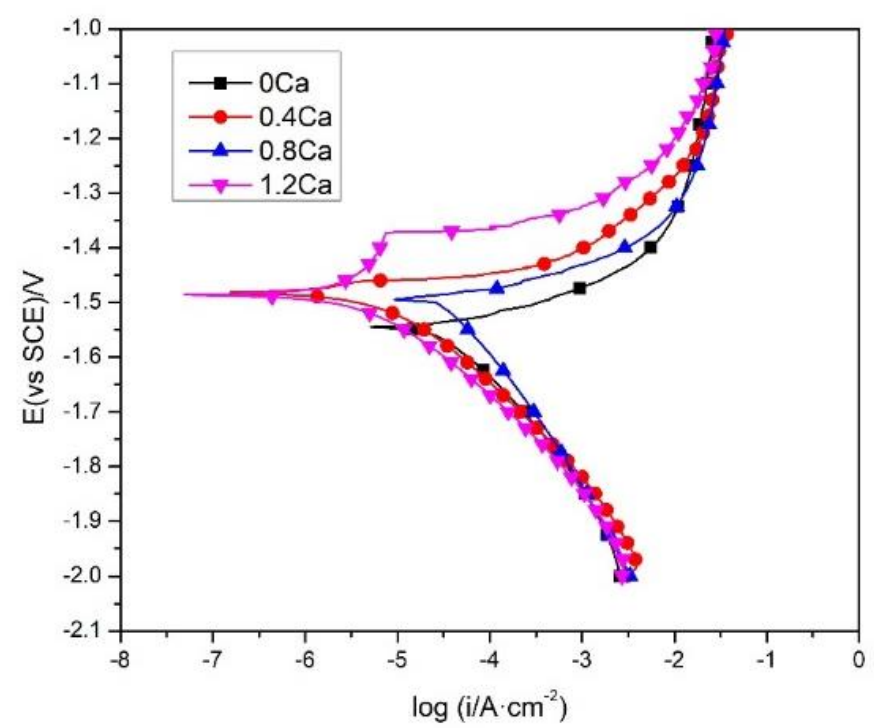

Figure 7. Potentiodynamic polarization curves of the extruded $\mathrm{Mg}-7 \mathrm{Li}-3 \mathrm{Al}-\mathrm{xCa}$ alloys. The measurements were performed in a $3.5 \mathrm{wt} . \% \mathrm{NaCl}$ solution.

The Nyquist and Bode plots of the samples are presented in Figure 8. As shown in Figure 8a, the Nyquist plots of all the experimental alloys consist of one capacitive loop in the high-frequency region and another capacitive loop in the low-frequency region. The appearance of the capacitive loop in the high-frequency region is mainly due to the transfer of charge, while its presence in the low-frequency region is mainly due to material transfer; the low-frequency resistance reflects the initiation of corrosion. The radius value of the loops of the experimental alloys containing Ca were larger than those of the $\mathrm{Mg}-7 \mathrm{Li}-3 \mathrm{Al}$ alloy, indicating that the corrosion resistance of the $\mathrm{Mg}-7 \mathrm{Li}-3 \mathrm{Al}$ alloys containing $\mathrm{Ca}$ was better than the corrosion resistance of the $\mathrm{Mg}-7 \mathrm{Li}-3 \mathrm{Al}$ alloy. In addition, the largest radius value corresponded to the $\mathrm{Mg}-7 \mathrm{Li}-3 \mathrm{Al}-1.2 \mathrm{Ca}$ alloy, and the corrosion resistance of the alloys was as follows: Mg-7Li-3Al-1.2Ca $>$ Mg-7Li-3Al-0.4Ca $>$ Mg-7Li-3Al-0.8Ca $>\mathrm{Mg}-7 \mathrm{Li}-3 \mathrm{Al}$. These results are consistent result with the polarization curves.

From Figure $8 \mathrm{~b}$, the impedance value of the $\mathrm{Mg}-7 \mathrm{Li}-3 \mathrm{Al}-1.2 \mathrm{Ca}$ alloy was the highest at low frequency, among all samples. In general, the larger the impedance value in the Bode plot, the better the densification of the passivation film of the alloy. In Figure 8c, a prominent wave crest can be seen for all the samples at high frequencies because of the double-layer capacitance and the corresponding charge transfer resistance during the generation process of the corrosion products. Additionally, when the alloy contained $\mathrm{Ca}$, a small peak appeared in the low-frequency range, which corresponded to an increase in film resistance due to the accumulation of corrosion products.
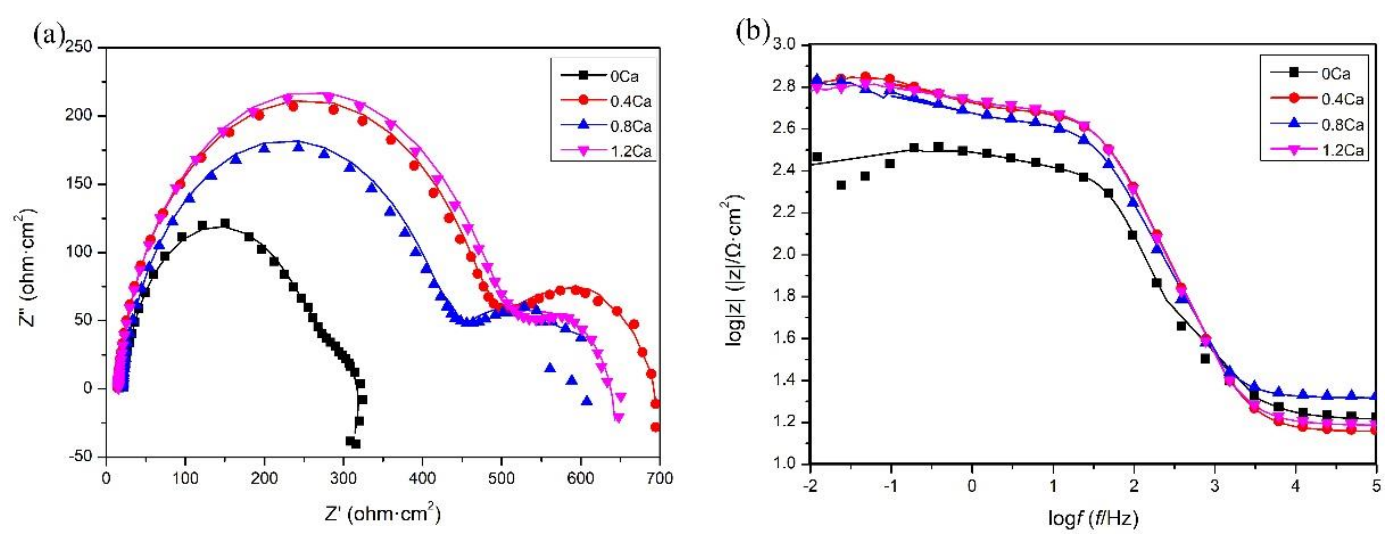

Figure 8. Cont. 


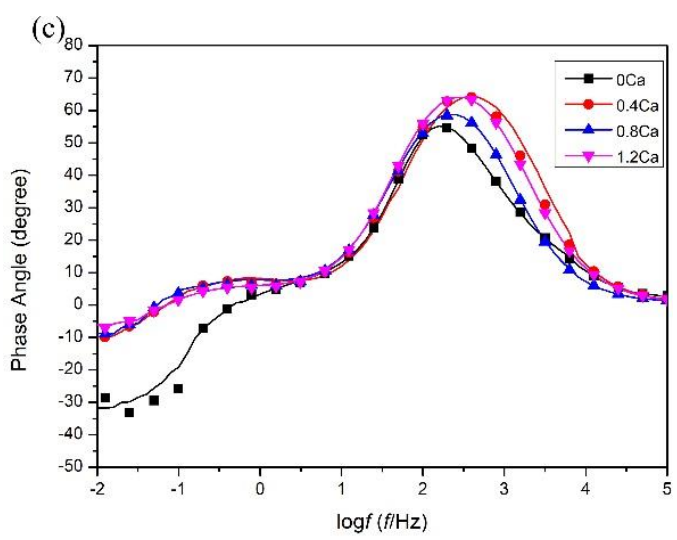

Figure 8. Impedance plots of the extruded $\mathrm{Mg}-7 \mathrm{Li}-3 \mathrm{Al}-\mathrm{xCa}$ alloys immersed in a $3.5 \mathrm{wt} . \% \mathrm{NaCl}$ solution. (a) Nyquist plots, (b) Bode plots, (c) Phase angle diagram.

Figure 9 shows the EIS spectra of the alloys, and the fitted results of the EIS measurement of the extruded Mg-7Li-3Al-xCa alloys are listed in Table 6. Here, $R_{s}, R_{c t}, R_{f}$, and CPE represent the solution resistance, charge transfer resistance, film resistance, and electric double-layer capacity, respectively. In general, higher values of $R_{c t}$ and $R_{f}$ indicate better corrosion resistance, while lower values of $C P E_{1}$ and $C P E_{2}$ indicate a Please check if the original meaning is retained and thicker film on the surface of the alloys $[25,26]$. The $\mathrm{Mg}-7 \mathrm{Li}-3 \mathrm{Al}-0.4 \mathrm{Ca}, \mathrm{Mg}-7 \mathrm{Li}-3 \mathrm{Al}-0.8 \mathrm{Ca}$, and $\mathrm{Mg}-7 \mathrm{Li}-3 \mathrm{Al}-1.2 \mathrm{Ca}$ alloys exhibited higher $R_{c t}$ and $R_{f}$ values than the $\mathrm{Mg}-7 \mathrm{Li}-3 \mathrm{Al}$ alloy, implying that the corrosion resistance of the extruded $\mathrm{Mg}-7 \mathrm{Li}-3 \mathrm{Al}$ alloy can be increased by the addition of Ca. Furthermore, the largest $R_{c t}$ and $R_{f}$ values were found for the $\mathrm{Mg}-7 \mathrm{Li}-3 \mathrm{Al}-1.2 \mathrm{Ca}$ alloy, demonstrating that the addition of $1.2 \mathrm{wt} . \% \mathrm{Ca}$ significantly improved the corrosion resistance of the alloy.

(a)

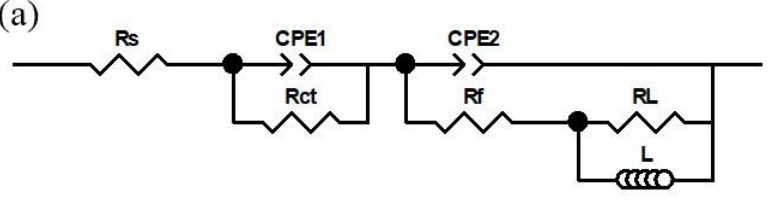

(b)

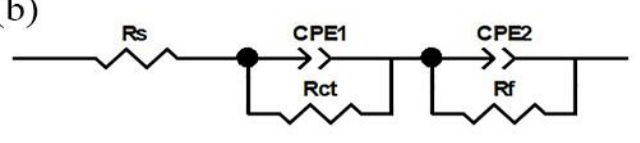

Figure 9. Equivalent circuits of the EIS spectra of (a) $\mathrm{Mg}-7 \mathrm{Li}-3 \mathrm{Al}, \mathrm{Mg}-7 \mathrm{Li}-3 \mathrm{Al}-0.4 \mathrm{Ca}$, and $\mathrm{Mg}-7 \mathrm{Li}-3 \mathrm{Al}-1.2 \mathrm{Ca}$ alloys, and (b) $\mathrm{Mg}-7 \mathrm{Li}-3 \mathrm{Al}-0.8 \mathrm{Ca}$ alloy.

Table 6. Fitted results of the EIS measurement of the extruded $\mathrm{Mg}-7 \mathrm{Li}-3 \mathrm{Al}-\mathrm{xCa}$ alloys using the equivalent circuits shown in Figure 9.

\begin{tabular}{|c|c|c|c|c|c|c|c|c|}
\hline $\begin{array}{c}\mathrm{Ca} \\
\text { Content }\end{array}$ & $R_{S}(\Omega)$ & $R_{c t}\left(\Omega \mathrm{cm}^{2}\right)$ & $\begin{array}{c}C P E_{1} \\
\left(10^{-6} \mathrm{~s}^{\mathrm{n}} \Omega^{-1} \mathrm{~cm}^{-2}\right)\end{array}$ & $\mathbf{n}_{1}$ & $R_{f}\left(\Omega \mathrm{cm}^{2}\right)$ & $\begin{array}{c}C P E_{2} \\
\left(\mathrm{~s}^{\mathrm{n}} \Omega^{-1} \mathrm{~cm}^{-2}\right)\end{array}$ & $n_{2}$ & $L$ \\
\hline $0 \mathrm{Ca}$ & 17.09 & 257.7 & 26.556 & 0.87955 & 14.6 & 0.00614 & 0.60395 & 20.75 \\
\hline $0.4 \mathrm{Ca}$ & 14.06 & 447.6 & 10.306 & 0.94147 & 235 & 0.00427 & 0.53179 & 231.9 \\
\hline $0.8 \mathrm{Ca}$ & 20.65 & 401.7 & 14.27 & 0.92142 & 189.1 & 0.00472 & 0.66559 & - \\
\hline $1.2 \mathrm{Ca}$ & 15.32 & 475.1 & 11.27 & 0.93109 & 241.4 & 0.00649 & 0.60237 & 140.6 \\
\hline
\end{tabular}

\subsection{Immersion Test}

As shown in Figure 10a, the hydrogen evolution of the $\mathrm{Mg}-7 \mathrm{Li}-3 \mathrm{Al}$ alloy was reached higher values than that of the alloys containing Ca. It can be seen from Figure 10a that in the first $12 \mathrm{~h}$, the hydrogen evolution rate was relatively slow, while between 12 and $30 \mathrm{~h}$, the hydrogen evolution rate significantly increased, because of the strong corrosiveness and high conductivity of $\mathrm{Cl}^{-}$, which accelerated ion transport and diffusion of $\mathrm{Mg}^{2+}$ during the corrosion process and promoted the corrosion of the alloy. With the extension of time, the hydrogen evolution rate after $30 \mathrm{~h}$ decreased significantly owing to the increase of corrosion products formed on the surface of the alloy that filled the gaps on the surface oxide film to some extent, slowing down the corrosion process. In addition, the corresponding corrosion rates 
were $5.50,1.73,2.93$, and $1.56 \mathrm{~mm} /$ year for the $\mathrm{Mg}-7 \mathrm{Li}-3 \mathrm{Al}, \mathrm{Mg}-7 \mathrm{Li}-3 \mathrm{Al}-0.4 \mathrm{Ca}, \mathrm{Mg}-7 \mathrm{Li}-3 \mathrm{Al}-0.8 \mathrm{Ca}$, and $\mathrm{Mg}-7 \mathrm{Li}-3 \mathrm{Al}-1.2 \mathrm{Ca}$ alloys, respectively. The $C_{w}$ rate and the volume of hydrogen evolution for the alloys containing $\mathrm{Ca}$ were slightly lower than those of the $\mathrm{Mg}-7 \mathrm{Li}-3 \mathrm{Al}$ alloy, indicating that $\mathrm{Ca}$ addition had a significant effect on the corrosion resistance.
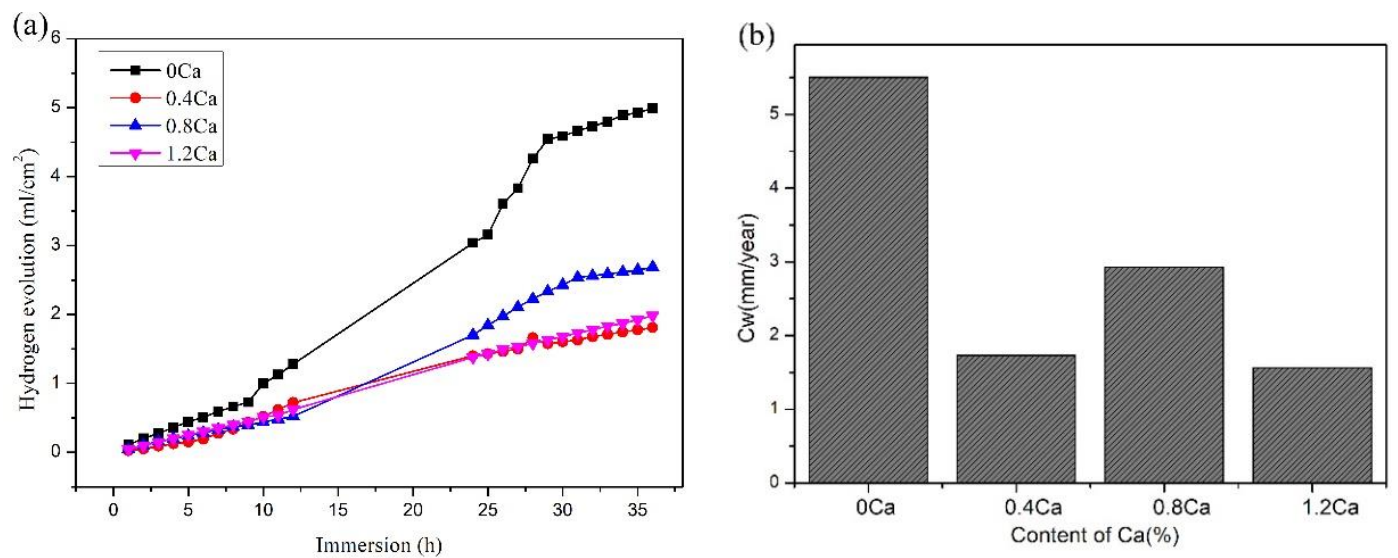

Figure 10. (a) Hydrogen evolution of the extruded Mg-7Li-3Al-xCa alloys immersed in a $3.5 \mathrm{wt} . \%$ $\mathrm{NaCl}$ solution, $(\mathbf{b})$ Corrosion rates $\left(C_{w}\right)$ of the extruded $\mathrm{Mg}-7 \mathrm{Li}-3 \mathrm{Al}-\mathrm{xCa}$ alloys immersed in a $3.5 \mathrm{wt} . \%$ $\mathrm{NaCl}$ solution for 7 days.

\section{Discussion}

\subsection{Effect of $\mathrm{Ca}$ Content on the Strength of Extruded $\mathrm{Mg}-7 \mathrm{Li}-3 \mathrm{Al}-x \mathrm{Ca}$ Alloys}

The addition of Ca refines the microstructure of $\mathrm{Mg}-7 \mathrm{Li}-3 \mathrm{Al}-$ based alloys. In addition, dynamic recrystallization leads to grain refinement during hot extrusion, as indicated by the Hall-Petch formula:

$$
\sigma=\sigma_{0}+K d^{-1 / 2}
$$

where $\sigma$ is the yield stress, $\sigma_{0}$ is the yield strength of a single crystal ( $\sigma_{0}=11 \mathrm{MPa} / \mu \mathrm{m}^{2}$ for $\left.\mathrm{Mg}\right), K$ is the Hall-Petch slope $\left(K=0.28 \mathrm{MNm}^{-3 / 2}\right.$ for $\mathrm{Mg}$ [27]), and $d$ is the average grain size. Therefore, this is probably the reason why the $\mathrm{Mg}-7 \mathrm{Li}-3 \mathrm{Al}-0.4 \mathrm{Ca}$ alloy showed the highest strength among the alloys.

With the addition of $\mathrm{Ca}$, the $\mathrm{Al}_{2} \mathrm{Ca}$ phase formed. When this second phase ( $\mathrm{Al}_{2} \mathrm{Ca}$ phase) was uniformly distributed in the matrix phase with finely dispersed particles, a significant strengthening effect was produced. The strength of the alloys can be estimated from the following Equation [5]:

$$
\sigma=f_{m} \sigma_{m}+f_{h} \sigma_{h}
$$

where $\sigma, \sigma_{m}$, and $\sigma_{h}$ are the strength of the $\mathrm{Mg}-7 \mathrm{Li}-3 \mathrm{Al}-\mathrm{xCa}$ alloys, $\mathrm{Mg}-7 \mathrm{Li}-3 \mathrm{Al}$ matrix alloy, and $\mathrm{Al}_{2} \mathrm{Ca}$ phase, respectively, and $f_{m}$ and $f_{h}$ are the volume fractions of the matrix alloys and $\mathrm{Al}_{2} \mathrm{Ca}$ particulates, respectively. The volume fraction of $\mathrm{Al}_{2} \mathrm{Ca}$ increased with increasing $\mathrm{Ca}$ content, resulting in an improvement in the strength of the alloys.

However, the yield strength of the $\mathrm{Mg}-7 \mathrm{Li}-3 \mathrm{Al}-1.2 \mathrm{Ca}$ alloy was lower than those of the $\mathrm{Mg}-7 \mathrm{Li}-3 \mathrm{Al}$ and $\mathrm{Mg}-7 \mathrm{Li}-3 \mathrm{Al}-0.4 \mathrm{Ca}$ alloys at room temperature, which contrasts with the results discussed above. According to a previous study [28], the morphology and size of the second phase have a great influence on the mechanical properties of an alloy. Large second-phase particles in the alloy can decrease the strength of the material. In particular, the high concentration of stress that may occur on these large particles during plastic tensile deformation ultimately leads to crack initiation and fracture at relatively early stages of the tensile test. The average size of these strip-shaped compounds shown in Figure $4 \mathrm{~d}$ was approximately $16.31 \mu \mathrm{m}$, which resulted in worse mechanical properties of the $\mathrm{Mg}-7 \mathrm{Li}-3 \mathrm{Al}-1.2 \mathrm{Ca}$ alloy compared to the $\mathrm{Mg}-7 \mathrm{Li}-3 \mathrm{Al}$ and $\mathrm{Mg}-7 \mathrm{Li}-3 \mathrm{Al}-0.4 \mathrm{Ca}$ alloys. 


\subsection{Corrosion Mechanism of the Extruded Mg-7Li-3Al-xCa Alloys}

According to Figure 11, the corrosion area of the extruded $\mathrm{Mg}-7 \mathrm{Li}-3 \mathrm{Al}$ alloy was larger than that of the other alloys, which implies that the corrosion resistance of the extruded $\mathrm{Mg}-7 \mathrm{Li}-3 \mathrm{Al}$ alloy was the worst. For the $\mathrm{Mg}-7 \mathrm{Li}-3 \mathrm{Al}-0.4 \mathrm{Ca}$ alloys, many corrosion pits and some amount of $\mathrm{Al}_{2} \mathrm{Ca}$ existed in the matrix, as presented in Figure 11b, demonstrating that the matrix corroded due to its lower electrical potential with respect to that of $\mathrm{Al}_{2} \mathrm{Ca}$. In Figure 11c, the corroded surface of the $\mathrm{Mg}-7 \mathrm{Li}-3 \mathrm{Al}-0.8 \mathrm{Ca}$ alloy was similar to that of the $\mathrm{Mg}-7 \mathrm{Li}-3 \mathrm{Al}-0.4 \mathrm{Ca}$ alloy. On the corroded surface of the $\mathrm{Mg}-7 \mathrm{Li}-3 \mathrm{Al}-1.2 \mathrm{Ca}$ alloy, the white areas corresponding to $\mathrm{Al}_{2} \mathrm{Ca}$ significantly increased and gathered into a line shape, which led to the aggregation of corrosion pits.
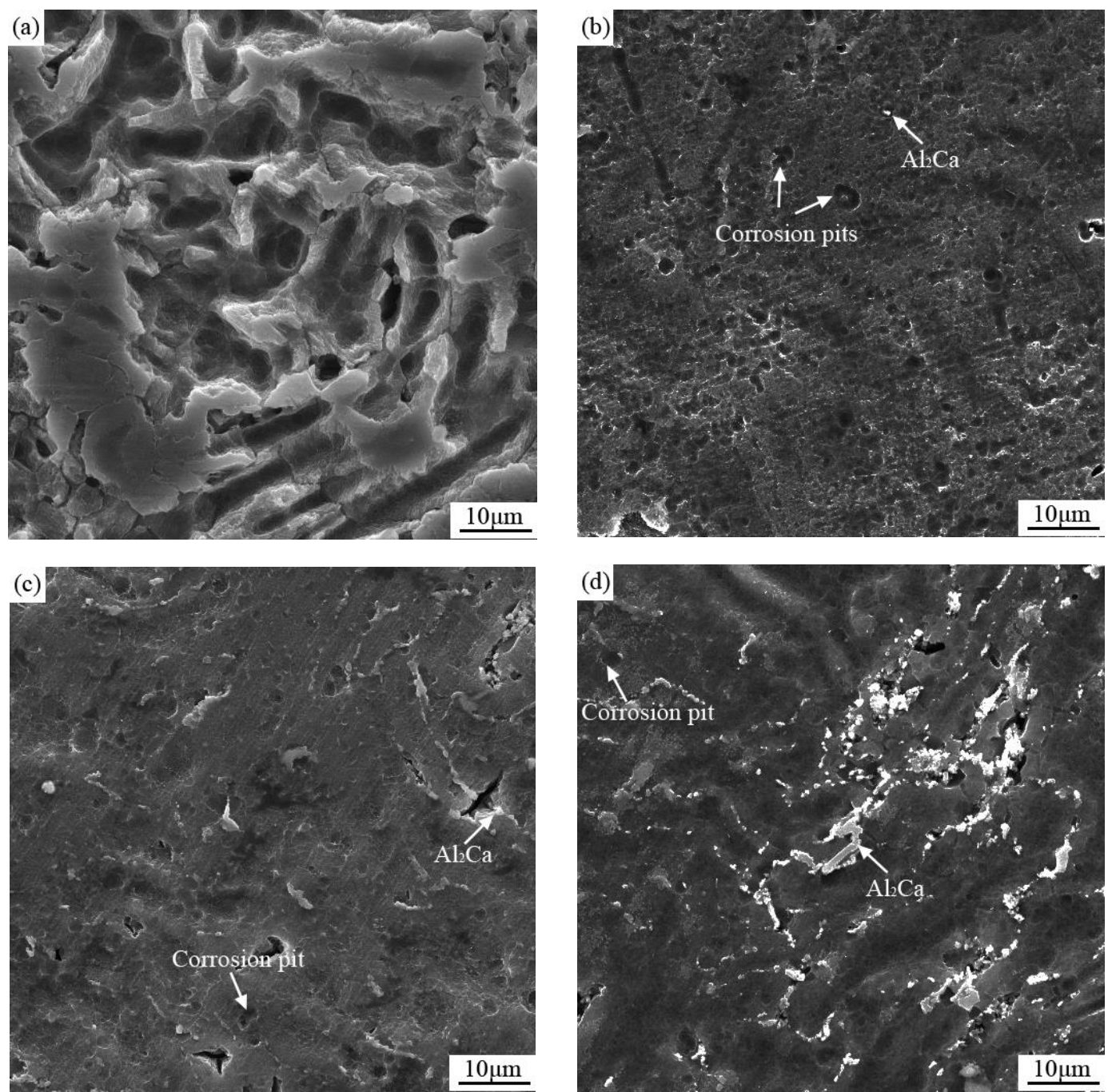

Figure 11. Corroded surfaces of the extruded $\mathrm{Mg}-7 \mathrm{Li}-3 \mathrm{Al}-\mathrm{xCa}$ alloys after immersion for $72 \mathrm{~h}$ in a 3.5 wt. $\% \mathrm{NaCl}$ solution at $25{ }^{\circ} \mathrm{C}:(\mathbf{a}) \mathrm{x}=0(\mathbf{b}) \mathrm{x}=0.4(\mathbf{c}) \mathrm{x}=0.8(\mathbf{d}) \mathrm{x}=1.2$.

The corrosion of the extruded $\mathrm{Mg}$ alloys is a dissolution process, mainly occurring on the bare parts of the Mg substrate. The reaction equations are as follows [16,29]:

$$
\text { Cathodic reaction : } 2 \mathrm{H}_{2} \mathrm{O}+2 \mathrm{e}^{-} \rightarrow \mathrm{H}_{2} \uparrow+2 \mathrm{OH}^{-}
$$

$$
\text { Anodic reaction }: \mathrm{Mg} \rightarrow \mathrm{Mg}^{2+}+2 \mathrm{e}^{-}
$$

Corrosion product formation : $\mathrm{Mg}+2 \mathrm{OH}^{-} \rightarrow \mathrm{Mg}(\mathrm{OH})_{2} \downarrow$ 
As for the extruded Mg-7Li-3Al alloy, additional reactions (7)-(10) can occur.

$$
\begin{gathered}
\text { Anodic reaction }: \mathrm{Li} \rightarrow \mathrm{Li}^{+}+\mathrm{e}^{-} \\
\mathrm{Al} \rightarrow \mathrm{Al}^{3+}+3 \mathrm{e}^{-} \\
\text {Corrosion product formation }: \mathrm{Li}+\mathrm{OH}^{-} \rightarrow \mathrm{Li}(\mathrm{OH}) \downarrow \\
\mathrm{Al}+3 \mathrm{OH}^{-} \rightarrow \mathrm{Al}(\mathrm{OH})_{3} \downarrow
\end{gathered}
$$

Generally, these corrosion products can form a protective film that prevents corrosion in the presence of a corrosive solution. However, the main corrosion product, $\mathrm{Mg}(\mathrm{OH})_{2}$, has many pores, enabling the surrounding solution to continuously penetrate the surface film and react with the exposed inner matrix.

When $\mathrm{Ca}$ was added to the $\mathrm{Mg}-7 \mathrm{Li}-3 \mathrm{Al}$ alloy, the formed $\mathrm{Al}_{2} \mathrm{Ca}$ phase had a significant effect on the corrosion of the extruded alloy. Taking the $\mathrm{Mg}-7 \mathrm{Li}-3 \mathrm{Al}-0.4 \mathrm{Ca}$ alloy as an example, the corrosion mechanism of Ca-containing extruded alloys is illustrated in Figure 12. Figure 13 presents micrographs of the corrosion at different stages for the extruded $\mathrm{Mg}-7 \mathrm{Li}-3 \mathrm{Al}-0.4 \mathrm{Ca}$ alloy after immersion in the $3.5 \mathrm{wt} . \% \mathrm{NaCl}$ solution. In general, intermetallic phases, such as $\mathrm{Al}_{2} \mathrm{Ca}$ particles, are chemically more stable than the $\alpha-\mathrm{Mg}+\beta-\mathrm{Li}$ matrix. Notably, previous studies have indicated that the corrosion resistance of the $\alpha-\mathrm{Mg}$ phase is superior to that of the $\beta$-Li phase $[29,30]$. Thus, in stage 1 , as shown in Figure 12, micro-galvanic couples first formed between the $\mathrm{Al}_{2} \mathrm{Ca}$ particles and the $\beta$-Li phases in the matrix. Corrosion first appeared at the surface of the sample, as presented in Figure 13a. Furthermore, in stage 2, the $\beta$-Li phase containing $\mathrm{Al}_{2} \mathrm{Ca}$ particles corroded and dissolved, leading to the formation of corrosion pits, as shown in Figure 13b. In addition, micro-galvanic couples started to form between the $\mathrm{Al}_{2} \mathrm{Ca}$ particles and the $\alpha-\mathrm{Mg}$ phase. In stage 3, the $\alpha-\mathrm{Mg}$ phase containing $\mathrm{Al}_{2} \mathrm{Ca}$ particles dissolved and formed corrosion pits. Moreover, the corrosion rate of the $\beta$-Li phase increased significantly, resulting in the formation of grooves (Figure 13c) and in $\mathrm{Al}_{2} \mathrm{Ca}$ particle detachment. After the corrosion of the matrix containing $\mathrm{Al}_{2} \mathrm{Ca}$ particles, the interface of the $\beta-\mathrm{Li}$ and $\alpha-\mathrm{Mg}$ phases was susceptible to localized corrosion. This localized corrosion initiated at the boundary of the $\alpha$-Mg and $\beta$-Li phases and then extended toward the more active $\beta$-Li phase, as shown in Figure 13d,e. In the stage 4, after the $\alpha-\mathrm{Mg}+\beta$-Li phases dissolved completely, $\mathrm{Al}_{2} \mathrm{Ca}$ separated from the matrix; a post-corrosion micrograph is presented in Figure 13f. Compared with Mg-7Li-3Al-0.4Ca, Mg-7Li-3Al-0.8Ca contains a high amount of secondary phases and more micro-galvanic couples, which determined a higher corrosion rate, while the $\mathrm{Mg}-7 \mathrm{Li}-3 \mathrm{Al}-0.4 \mathrm{Ca}$ alloy showed the best corrosion resistance. The reason for this phenomenon can be that the addition of 1.2Ca led to grain refinement. Previous reports demonstrated that the grain boundaries can not only provide nucleation sites for the passivation films [31] but also act as a physical corrosion barrier [32], indicating that a small grain size can improve the corrosion resistance.

Compared with the corrosion behavior of the extruded alloys containing $\mathrm{Ca}$, the dissolution of the $\alpha-\mathrm{Mg}+\beta$-Li matrix in the extruded $\mathrm{Mg}-7 \mathrm{Li}-3 \mathrm{Al}$ alloy resulted in a larger corrosion area. When Ca was added to the alloys, the corrosion resistance of the extruded alloys significantly improved. This occurred because the corrosion mechanism changed from local corrosion, initiated at the phase boundaries of the extruded $\mathrm{Mg}-7 \mathrm{Li}-3 \mathrm{Al}$ alloy, to pitting corrosion starting on the $\mathrm{Al}_{2} \mathrm{Ca}$ particles of the extruded alloys containing $\mathrm{Ca}$. Therefore, the corrosion resistance of the extruded alloys containing $\mathrm{Ca}$ was better than that of the extruded $\mathrm{Mg}-7 \mathrm{Li}-3 \mathrm{Al}$ alloy. 


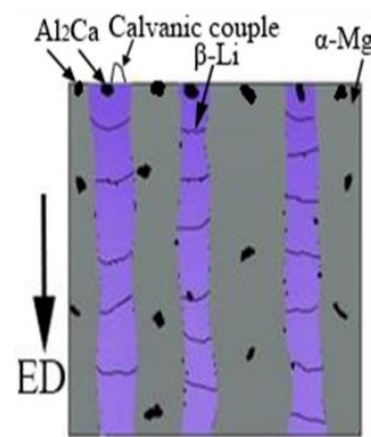

Stage 1

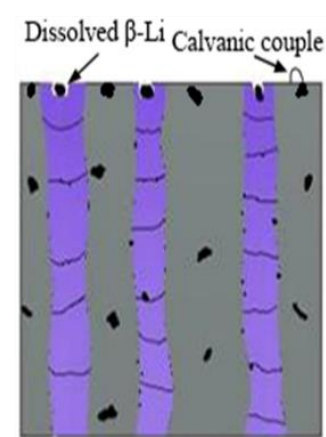

Stage 2

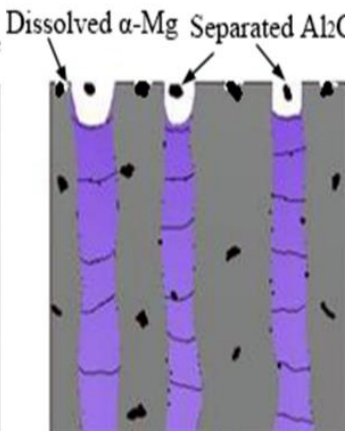

Stage 3

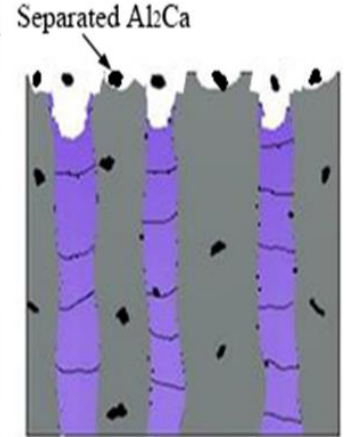

Stage 4

Figure 12. Schematic illustration of the role of the secondary phases in the extruded $\mathrm{Mg}-7 \mathrm{Li}-3 \mathrm{Al}-\mathrm{xCa}$ alloys where their distribution is discontinuous.
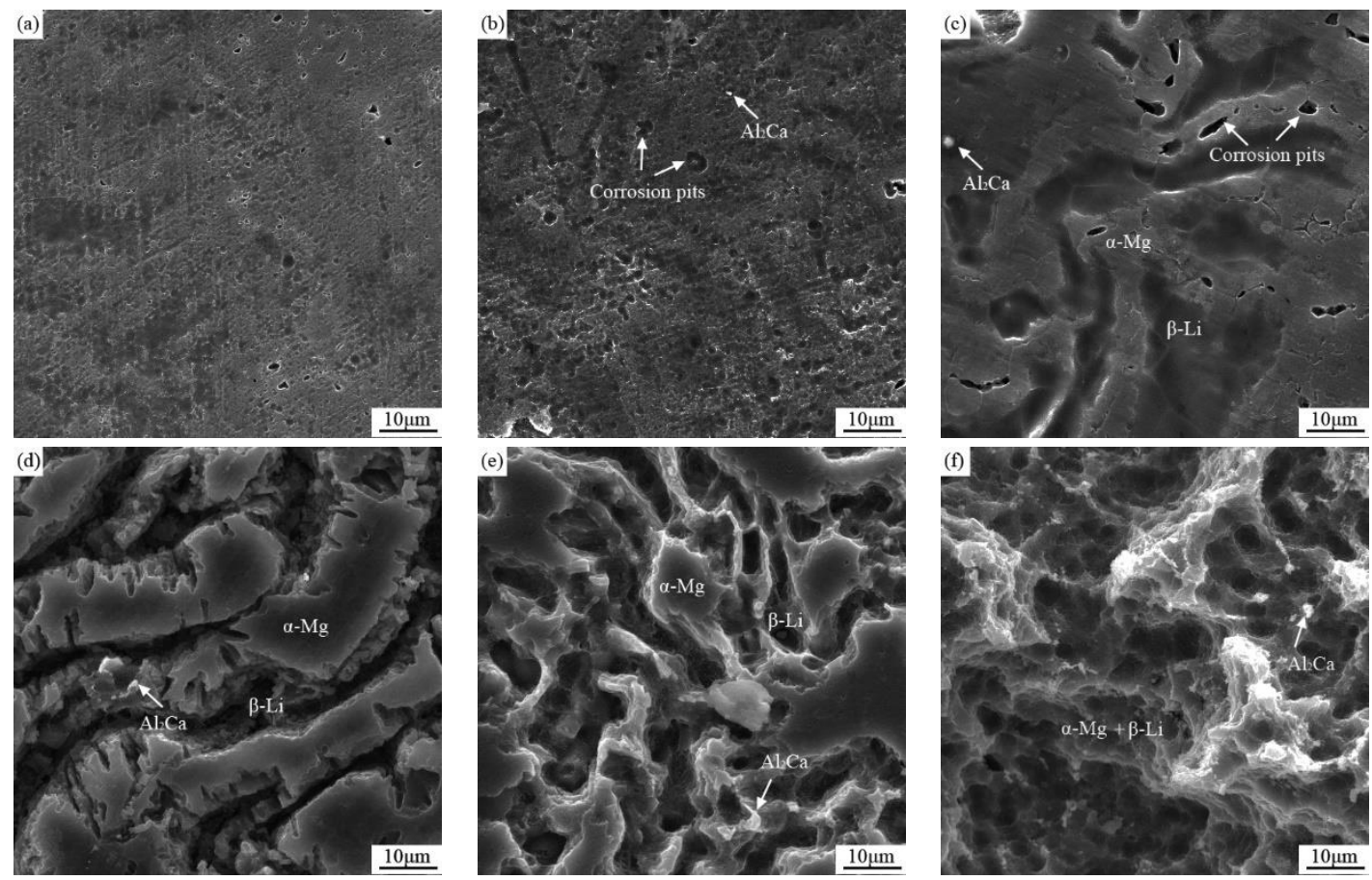

Figure 13. Micrographs showing corrosion at different times in the extruded $\mathrm{Mg}-7 \mathrm{Li}-3 \mathrm{~A}-0.4 \mathrm{Ca}$ alloy after immersion in a $3.5 \mathrm{wt} . \% \mathrm{NaCl}$ solution at $25^{\circ} \mathrm{C}$. (a) $6 \mathrm{~h} \mathrm{(b)} 12 \mathrm{~h} \mathrm{(c)} 24 \mathrm{~h}$ (d) $48 \mathrm{~h} \mathrm{(e)} 60 \mathrm{~h}$ (f) $72 \mathrm{~h}$.

\section{Conclusions}

(1) The grains of extruded $\mathrm{Mg}-7 \mathrm{Li}-3 \mathrm{Al}-\mathrm{xCa}$ alloys were significantly refined as a result of dynamic recrystallization during the extrusion process. The $\alpha$-Mg and $\beta$-Li phases were elongated along the extrusion direction. $\mathrm{Al}_{2} \mathrm{Ca}$ in the alloys formed and mainly distributed at the boundaries of the $\alpha$-Mg and $\beta$-Li phases and at the grain boundaries.

(2) With increasing Ca content, the strength of the extruded $\mathrm{Mg}-7 \mathrm{Li}-3 \mathrm{Al}-\mathrm{xCa}$ alloys first increased and then decreased. The extruded $\mathrm{Mg}-7 \mathrm{Li}-3 \mathrm{Al}-0.4 \mathrm{Ca}$ alloy exhibited favorable mechanical performance, demonstrating a UTS of $286 \mathrm{MPa}$, a TYS of $249 \mathrm{MPa}$, and elongation of $18.7 \%$. The extruded Mg-7Li-3Al-0.8Ca alloy exhibited favorable mechanical properties at $423 \mathrm{~K}$ (150 $\left.{ }^{\circ} \mathrm{C}\right)$, with an UTS of $191 \mathrm{MPa}$.

(3) The addition of Ca can improve the corrosion resistance of the extruded $\mathrm{Mg}-7 \mathrm{Li}-3 \mathrm{Al}$ alloy, which is attributed to the formation of $\mathrm{Al}_{2} \mathrm{Ca}$ particles. The corrosion mechanism of the extruded $\mathrm{Mg}-7 \mathrm{Li}-3 \mathrm{Al}$ alloy is local corrosion initiated at the phase boundaries, while for the extruded alloys containing $\mathrm{Ca}$, the corrosion mechanism is pitting corrosion starting on the $\mathrm{Al}_{2} \mathrm{Ca}$ particles. 
Author Contributions: Y.Y., X.P. and X.X. conceived and designed the experiments; X.X. and H.D. performed the experiments; X.X., H.D., M.L. and J.L. analyzed the data; X.X. and G.W. contributed reagents/materials/analysis tools; X.X. wrote the paper, Y.Y., X.P. and H.D. writing-review and editing the paper.

Funding: National Natural Science Foundation of China: No. 51601024; National Key Research and Development Program of China: No. 2016YFB0700403; National Key Research and Development Program of China: No. 2016YFB0301100; Fundamental Research Funds for the Central Universities of china: No. 2018CDJDCL0020; Fundamental Research Funds for the Central Universities of china: No. 2018CDJDCL0019; Fundamental Research Funds for the Central Universities of china: No. 2018CDGFCL0005; Ministry of Education and the State Administration of Foreign Experts Affairs of China: No. B16007.

Acknowledgments: The authors acknowledge financial support by the National Natural Science Foundation (Project No. 51601024), the National Key Research and Development Program of China (Project No. 2016YFB0700403 \& Project No. 2016YFB0301100), the Fundamental Research Funds for the Central Universities (Project No. 2018CDJDCL0019, Project No. 2018CDJDCL0020 and Project No. 2018CDGFCL0005) and the support of the 111 Project (Project No. B16007) by the Ministry of Education and the State Administration of Foreign Experts Affairs of China.

Conflicts of Interest: The authors declare no conflict of interest

\section{References}

1. Mahmudi, R.; Shalbafi, M.; Karami, M.; Geranmayeh, A.R. Effect of Li content on the indentation creep characteristics of cast Mg-Li-Zn alloys. Mater. Des. 2015, 75, 184-190. [CrossRef]

2. Li, J.; Qu, Z.; Wu, R.; Zhang, M. Effects of $\mathrm{Cu}$ addition on the microstructure and hardness of $\mathrm{Mg}-5 \mathrm{Li}-3 \mathrm{Al}-2 \mathrm{Zn}$ alloy. Mater. Sci. Eng. A 2010, 527, 2780-2783. [CrossRef]

3. Yang, Q.; Jiang, B.; Li, J.; Dong, H.; Liu, W.; Luo, S.; Pan, F. Modified texture and room temperature formability of magnesium alloy sheet by Li addition. Int. J. Mater. Mater. Form. 2016, 9, 305-311. [CrossRef]

4. Zhang, J.; Liu, S.; Wu, R.; Hou, L.; Zhang, M. Recent developments in high-strength Mg-RE-based alloys: Focusing on Mg-Gd and Mg-Y systems. J. Magnes. Alloy. 2018, 6, 277-291. [CrossRef]

5. Yang, Y.; Peng, X.; Wen, H.; Zheng, B.; Zhou, Y.; Xie, W.; Lavernia, E.J. Influence of Extrusion on the Microstructure and Mechanical Behavior of Mg-9Li-3Al-xSr Alloys. Metall. Mater. Trans. A Phys. Metall. Mater. Sci. 2013, 44, 1101-1113. [CrossRef]

6. Majd, A.M.; Farzinfar, M.; Pashakhanlou, M.; Nayyeri, M.J. Effect of RE elements on the microstructural and mechanical properties of as-cast and age hardening processed Mg-4Al-2Sn alloy. J. Magnes. Alloy. 2018, 6, 309-317. [CrossRef]

7. Zha, M.; Zhang, H.-M.; Wang, C.; Wang, H.-Y.; Zhang, E.-B.; Jiang, Q.-C. Prominent role of a high volume fraction of Mg17 Al12 particles on tensile behaviors of rolled Mg-Al-Zn alloys. J. Alloys Compd. 2017, 728, 682-693. [CrossRef]

8. Zhou, Y.-L.; Li, Y.; Luo, D.-M.; Wen, C.; Hodgson, P. Microstructures, mechanical properties and in vitro corrosion behaviour of biodegradable Mg-Zr-Ca alloys. J. Mater. Sci. 2012, 48, 1632-1639. [CrossRef]

9. Xiang, Q.; Jiang, B.; Zhang, Y.; Chen, X.; Song, J.; Xu, J.; Fang, L.; Pan, F. Effect of rolling-induced microstructure on corrosion behaviour of an extruded Mg-5Li-1Al alloy sheet. Corros. Sci. 2017, 119, 14-22. [CrossRef]

10. Peng, Q.Z.; Zhou, H.T.; Zhong, F.H.; Ding, H.B.; Zhou, X.; Liu, R.R.; Xie, T.; Peng, Y. Effects of homogenization treatment on the microstructure and mechanical properties of Mg-8Li-3Al-Y alloy. Mater. Des. 2015, 66, 566-574. [CrossRef]

11. Jiang, Z.; Jiang, B.; Yang, H.; Yang, Q.; Dai, J.; Pan, F. Influence of the Al2Ca phase on microstructure and mechanical properties of Mg-Al-Ca alloys. J. Alloys Compd. 2015, 647, 357-363. [CrossRef]

12. Liu, Q.; Zhou, X.; Zhou, H.; Fan, X.; Liu, K. The effect of extrusion conditions on the properties and textures of AZ31B alloy. J. Magnes. Alloy. 2017, 5, 202-209. [CrossRef]

13. Cao, F.; Xia, F.; Hou, H.; Ding, H.; Li, Z. Effects of high-density pulse current on mechanical properties and microstructure in a rolled Mg-9.3Li-1.79Al-1.61Zn alloy. Mater. Sci. Eng. A 2015, 637, 89-97. [CrossRef]

14. Fu, X.; Yang, Y.; Hu, J.; Su, J.; Zhang, X.; Peng, X. Microstructure and mechanical properties of as-cast and extruded Mg-8Li-1Al-0.5Sn alloy. Mater. Sci. Eng. A 2018, 709, 247-253. [CrossRef]

15. Homayun, B.; Afshar, A. Microstructure, mechanical properties, corrosion behavior and cytotoxicity of Mg-Zn-Al-Ca alloys as biodegradable materials. J. Alloys Compd. 2014, 607, 1-10. [CrossRef]

16. Yang, J.; Peng, J.; Nyberg, E.A.; Pan, F. Effect of Ca addition on the corrosion behavior of Mg-Al-Mn alloy. Appl. Surf. Sci. 2016, 369, 92-100. [CrossRef] 
17. Kim, K.H.; Nam, N.D.; Kim, J.G.; Shin, K.S.; Jung, H.C. Effect of calcium addition on the corrosion behavior of Mg-5Al alloy. Intermetallics 2011, 19, 1831-1838. [CrossRef]

18. Kondori, B.; Mahmudi, R. Effect of Ca additions on the microstructure, thermal stability and mechanical properties of a cast AM60 magnesium alloy. Mater. Sci. Eng. A 2010, 527, 2014-2021. [CrossRef]

19. Zhang, L.; Deng, K.; Nie, K.; Xu, F.; Su, K.; Liang, W. Microstructures and mechanical properties of Mg-Al-Ca alloys affected by Ca/Al ratio. Mater. Sci. Eng. A 2015, 636, 279-288. [CrossRef]

20. Watanabe, H.; Yamaguchi, M.; Takigawa, Y.; Higashi, K. Mechanical properties of Mg-Al-Ca alloy processed by hot extrusion. Mater. Sci. Eng. A 2007, 454, 384-388. [CrossRef]

21. Nene, S.S.; Kashyap, B.P.; Prabhu, N.; Estrin, Y.; Al-Samman, T. Microstructure refinement and its effect on specific strength and bio-corrosion resistance in ultralight $\mathrm{Mg}-4 \mathrm{Li}-1 \mathrm{Ca}$ (LC41) alloy by hot rolling. J. Alloys Compd. 2014, 615, 501-506. [CrossRef]

22. Wang, T.; Wu, R.; Zhang, M.; Li, L.; Zhang, J.; Li, J. Effects of calcium on the microstructures and tensile properties of Mg-5Li-3Al alloys. Mater. Sci. Eng. A 2011, 528, 5678-5684. [CrossRef]

23. Yang, Y.; Xiong, X.; Su, J.; Peng, X.; Wen, H.; Wei, G.; Pan, F.; Lavernia, E.J. Influence of extrusion temperature on microstructure and mechanical behavior of duplex Mg-Li-Al-Sr alloy. J. Alloys Compd. 2018, 750, 696-705. [CrossRef]

24. Wu, P.; Xu, F.; Deng, K.; Han, F.; Zhang, Z.; Gao, R. Effect of extrusion on corrosion properties of Mg-2Ca-xAl $(\mathrm{x}=0,2,3,5)$ alloys. Corros. Sci. 2017, 127, 280-290. [CrossRef]

25. Li, J.; Jiang, Q.; Sun, H.; Li, Y. Effect of heat treatment on corrosion behavior of AZ63 magnesium alloy in 3.5 wt.\% sodium chloride solution. Corros. Sci. 2016, 111, 288-301. [CrossRef]

26. Udhayan, R.; Bhatt, D.P. On the corrosion behaviour of magnesium and its alloys using electrochemical techniques. J. Power Sources 1996, 63, 103-107. [CrossRef]

27. Kim, W.J.; Moon, I.K.; Han, S.H. Ultrafine-grained Mg-Zn-Zr alloy with high strength and high-strain-rate superplasticity. Mater. Sci. Eng. A 2012, 538, 374-385. [CrossRef]

28. Park, S.H.; Jung, J.; Yoon, J.; You, B.S. Influence of Sn addition on the microstructure and mechanical properties of extruded Mg-8Al-2Zn alloy. Mater. Sci. Eng. A 2015, 626, 128-135. [CrossRef]

29. Zeng, R.; Sun, L.; Zheng, Y.; Cui, H.; Han, E. Corrosion and characterisation of dual phase Mg-Li-Ca alloy in Hank's solution: The influence of microstructural features. Corros. Sci. 2014, 79, 69-82. [CrossRef]

30. Li, C.Q.; Xu, D.K.; Chen, X.B.; Wang, B.J.; Wu, R.Z.; Han, E.H.; Birbilis, N. Composition and microstructure dependent corrosion behaviour of Mg-Li alloys. Electrochim. Acta 2018, 260, 55-64. [CrossRef]

31. Jeong, Y.S.; Kim, W.J. Enhancement of mechanical properties and corrosion resistance of Mg-Ca alloys through microstructural refinement by indirect extrusion. Corros. Sci. 2014, 82, 392-403. [CrossRef]

32. Aung, N.N.; Zhou, W. Effect of grain size and twins on corrosion behaviour of AZ31B magnesium alloy. Corros. Sci. 2010, 52, 589-594. [CrossRef]

(C) 2019 by the authors. Licensee MDPI, Basel, Switzerland. This article is an open access article distributed under the terms and conditions of the Creative Commons Attribution (CC BY) license (http://creativecommons.org/licenses/by/4.0/). 